X-ray satellite

\section{Odds on Thor}

AT a "restricted session" of its council last week, the European Space Agency (ESA) decided to lay the groundwork for a possible launch of the European X-ray astronomy satellite, EXOSAT, on a ThorDelta rocket from the US National Aeronautics and Space Administration (NASA), in case the present ground trials on Ariane lead to further delays in the European launching programme. A final decision as to whether the satellite is to be launched on the Ariane or on a Thor will be made on 23 February.

ESA has been under pressure from European astronomers to take the politically embarrassing step of a Thor launch ever since it became clear that delays in the Ariane programme (after the failure of L5, the fifth Ariane launch in September 1982) were likely to harm EXOSAT's scientific potential (see Nature 6 January, p.8). Last week's decision represents a formal acknowledgement that the problem exists and should be catered for. As a result, scientists from ESTEC, ESA's technical centre in the Netherlands, are visiting the United States to make contingency plans with NASA. The modifications required on the satellite to switch launchers would be minor.

The key question for ESA is whether there is time to launch EXOSAT before the end of the summer launch "window" for Ariane. EXOSAT is set to be carried by the seventh Ariane, L7, but before that L6 has to be launched. It is scheduled for May but is still undergoing trials of its turbo-pumps which have been modified to take account of the failings of L5. Although everybody is tight-lipped there are rumours that the launch of L6 may be delayed until June, which would barely leave time for L 7 to go up within the summer launch "window", given the expected turn around of about eight weeks for successive Ariane launches. If the rumours are true, therefore, a ThorDelta launch is virtually a certainty - and would take place from Vandenberg Air Force Base, California, in late June.

NASA will require notice for such a launch by the end of February. The financial consequences of such a decision by ESA are expected to be minor, but would depend on negotiations between ESA on the one hand and NASA and Arianespace on the other. One suggestion is that the money already paid for the $L 7$ launch could be banked by Arianespace as a future contribution to the cost of launching Giotto, ESA's mission to Halley's comet.

Despite the political embarrassment of such a move, it could have a compensatory benefit for Arianespace. There is a queue of communication satellites waiting for an Ariane launch, and Arianespace may well be relieved of pressure and uncertainty if EXOSAT is removed from its waiting list. Philip Campbell

\section{Instant winner}

Winner of the black-and-white light microscopy category in Polaroid Corporation's first worldwide instant photomicrography competition. The photograph is an enlargement of a polyester monofilament recorded in polarized monochromatic light on Polaroid Type 55 postive/negative film with a Carl Zeiss Ultraphot II microscope. It was taken by Karl Nettelnstroth, a microscopist at Hoechst AG in Frankfurt.

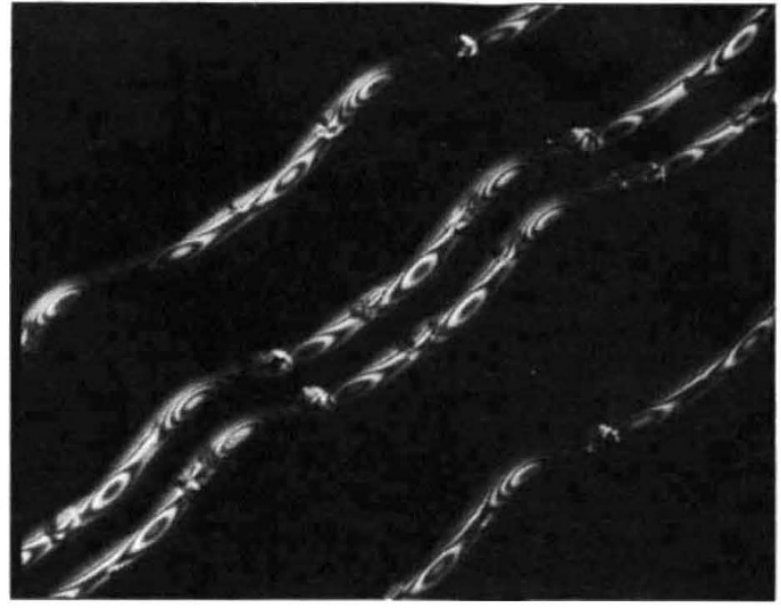

\section{Romania/US relations}

\section{Problems on both sides}

WESTERN countries are attempting to employ "'neocolonial", methods by recruiting academic skilled labour from Romania, a leading Bucharest daily newspaper, Romania Libera, alleged last week.

The claim, in an article which ostensibly reviewed the state of education in Romania, came only a few days after the return to the United States of Mr Lawrence Eagleburger, a senior State Department official who had visited Romania as a presidential envoy. A major part of $\mathrm{Mr}$ Eagleburger's mission was to explain to the Romanians the United States' attitude to the new Romanian emigration law which was suddenly promulgated last November. Under this law, every would-be emigrant would have to repay the Romanian state the total cost of his or her higher education, from the last two years of secondary school upwards. This sum, which could amount to as much as $\$ 50,000$, must be paid in "hard currency" - which Romanian citizens are forbidden to possess.

According to Romania Libera these measures have been introduced out of a "deeply patriotic concern for the patrimony of the Romanian people",

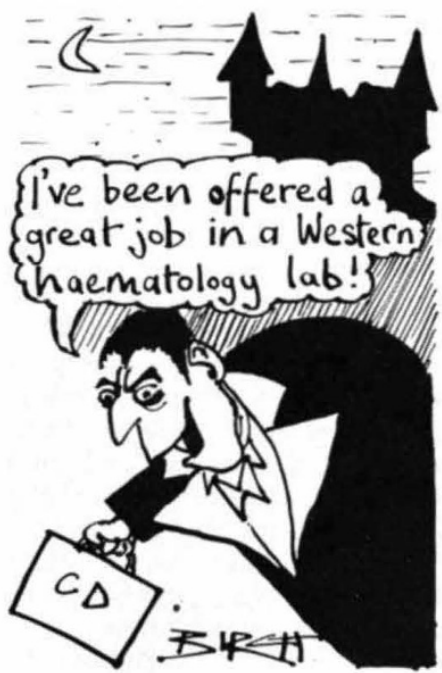

which, it says, has been exploited under various pretexts in the past. In fact, emigration is already virtually restricted to the 3,000 Jews and 12,000 ethnic Germans who in recent years have been allowed to leave annually for Israel or West Germany. The new law, if implemented, would reduce this annual flow to those few persons fortunate enough to have friends or relatives abroad to buy them out. Under Clause 504A of the United States Trade Act of 1974 (the "Jackson amendment"), the imposition of any such "education tax" on emigrants automatically excludes the country concerned from enjoying most favoured nation status (MFN) with the United States.

Should the new rule be implemented, the US Senate would be unable to renew Romania's MFN when it expires next June.

The announcement of the education tax last November drew an immediate response from the US State Department, deploring this move and drawing attention to Clause 504A. The strength of the American reaction - coupled with equally sharp criticism from West Germany and Israel - seems to have taken the Romanians by surprise. Nevertheless, during Mr Eagleburger's visit they continued to maintain that emigration is causing a serious "brain drain" and so it is only fair that the emigrants should repay the Romanian economy for its educational investment in them. This, however, does not explain why the emigrants cannot pay in Romanian currency.

So far no cases of emigrants having to repay education costs have been substantiated. The delay in implementing the law had raised hopes in the West that while not losing international face by formally abrogating the law, the Romanians might be intending to let it remain a dead letter. The tone of the Romania Libera article, and its timing so soon after Mr Eagleburger's visit, now make the fulfilment of such hopes unlikely.

Vera Rich 